\title{
Examining Relationship Between Political Agenda on Social media and Political Support Among University Students
}

\author{
ALI SALMAN \\ Universiti Malaysia Kelantan \\ MOHD AZUL MOHAMAD SALLEH \\ Universiti Kebangsaan Malaysia
}

\begin{abstract}
Social media have become the most readily available and important communication tools in the globalised world of today. As key sources of information, social media are responsible for delivering information and political news to the public making an impact on political support in Malaysia. Hence, the purpose of this study is to examine the role of social media in opening up space for political agenda and support among university students. A quantitative research approach using survey was used for data collection. A Questionnaire was used as an instrument to obtain data on the role of social media in political support among 200 respondents who were students of Universiti Kebangsaan Malaysia (UKM) and Universiti Putra Malaysia (UPM) in Klang Valley, Malaysia's business hub. Using the Agenda Setting Theory, this study attempts to measure the relationship between political agenda on social media and political support. The findings show that political agenda on social media has a significant relationship with political support. Moreover, political agenda on social media plays a major role in political support. The results further show that social media provides information for understanding political issues in the country and at the same time empowers the people to share information about politics. This implies that social media provide a space for students to engage in political discussion leading to political support.
\end{abstract}

Keywords: Political agenda, political support, social media, university students, youth.

\section{INTRODUCTION}

Social media have become the most readily available and important communication medium in the globalised world of today. These Internet-based applications allow users to contribute, respond openly and share information in a fast and timely manner. Facebook, WhatsApp, Twitter, Instagram, Path and Pinterest are among the more widely used social media apps. According to Internet Live Stats (http://www.Internetlivestats.com/), Internet users in Malaysia are estimated at $21,090,777$ out of a total population of $30,751,602$ or $68.6 \%$ as of July 1, 2016 and nearly 10 million citizens have Facebook, Twitter, blog accounts and so on. This development has created a new scenario in Malaysia.

In line with this convergence, social media have also opened up a space for society to engage in the political affairs of the country. In the political context, social media serve as the most influential 'power tool'. It provides a public sphere for people to express their political participation freely and without pressure (Utusan Online, 2015). The term general space or in 
German called offentlichkeit refers to a space or special area in a society where each individual can freely interact and thereby influence a political act (Utusan Online, 2015).

Social media today plays a big role in the political aspects of Malaysia and this can be seen by the community's involvement in the 14th General Elections that took place in Malaysia. After launching the Malaysia Media Week 2013 Summit on February 27, 2013, Najib emphasized that 'Of course, it (social media) certainly increases the tempo of political debate' (Lim, 2013, p.1). Here we can see that political engagement via social media has increased in our society.

Thus, Milbrath (1965) argues that there are 3 categories of political involvement namely apathetics, those who do not engage in politics or have withdrawn from the political process; spectators, who are minimally involved in politics, and gladiators who are really involved in politics. Political culture is a very broad topic on the behavior, involvement, perception, trust, and expectation of community members in the political environment (Ahmad Nidzamuddin, 2002).

Democracy through the internet today opens a new dimension in the process of communication and dissemination of information, especially among youths (Fatimah \& Ali, 2015). With this development, politicians took advantage and spread political agenda using all types of political messages that were able to influence young people. Social media are now used as tools by politicians to spread their political agenda. Subsequently, social media are also seen as media that facilitate the distribution of information, where information is accessible without restrictions. Even users are free to share, voice their opinions and increase their political participation. For example, "keyboard warrior" groups are willing to argue on Twitter and Facebook for the sake of the party they support.

It is undeniable that social media is seen as the most important tool used by youths in voicing their views on poltical issues, especially among public university (IPTA) students (Siti Ezaleila, 2016). Thus, it is worth examining the factors that encourage students to engage and voice their views on political affairs via social media, consequently leading to political support.

The purpose of this study is to examine and understand the role of social media that open up space for political support among university students. Based on the purpose of the study, three objectives were set out to be achieved: to identify the purpose of using social media; to identify the levels of political agenda on social media; and to evaluate the relationships between the purpose of using social media, political agenda in social media and political support among university students.

\section{LITERATURE REVIEW}

Trends in the use of social networks among active Malaysian consumers in a survey of 369 respondents showed that more people are using social media technology with the majority having more than one social media account. The survey indicated that people logged in multiple times a day and spent an average of two hours on each session - or up to 20 hours a week - to communicate or for social interaction. The findings also show that respondents seem to agree that social media is an extension and addition to offline interaction and that it will replace other media and communication tools in the near future (Siti Ezaleila, 2016).

Examining the role of social media as a mechanism to set the agenda in the Malaysian political scene, Ali et al. (2016) used secondary data sources to gain insights into the issue and 
the findings revealed that social media is important in shaping public opinion on political matters. The study suggested that the Agenda Setting Theory needs to be reviewed as the public agenda has taken the central stage through social media.

In a similar study by Fatimah and Ali (2015), the focus was on the use of new media as a platform that facilitates the distribution of information and providing unrestricted access to information. The purpose of the study was to examine the relationship between information democracy through the new media space and online and offline participation among urban youth. Data was randomly sampled from 250 respondents in Kajang and Bangi. The results showed that new media provide an avenue for information democracy and allow the youth to be active in political participation both online and offline

A survey conducted by Junaidi Awang and Mohd Fuad (2015) aimed at determining the influence of information sources in forming political support. This study also evaluated the differences that had taken place in the Malaysian political landscape before 1999 as the people then only relied on conventional media as the main source of information. The situation has since changed with the advent of the Internet as a source of information. The findings showed that respondents who accessed print and electronic media are more likely to support Barisan Nasional (The National Front) or popularly known as BN while respondents who access alternative sources such as blogs and social media are more likely to support parties in the opposition coalition, Pakatan Harapan. In fact, the most recent $14^{\text {th }}$ General Elections in 2018 revealed this trend where large numbers of young voters who sourced political information through social media voted Pakatan Harapan, loosely translated as the coalition of hope, into power.

Kahne and Bowyer (2018) examines the extent to which political issues can affect social media usage among students. The objective of the study was to identify the main factors affecting social media usage for political support among students. The results of the study found that $83 \%$ of the respondents had used social media over a period of 4 years and $63 \%$ are surfing social media to obtain information related to politics. The results of various regression tests found that the acceptance of information related to politics on social media has the interactive feature found in social media as a major contributor. The results of this study clearly show that most youth use social media to gain political influence.

Social media has impacted the community's involvement in current issues. These engagements include actively keeping up with current issues through blogs, forming online groups to deliver aspirations, blogging on current issues, commenting on online news, articles / blogs, participating in online discussion and downloading or spreading news related to current issues (Uzuegbunam, 2015; Ali \& Samsudin, 2012).

The effectiveness of social media in assisting opinion leaders to spread political ideology in Malaysia has been studied. Nuurrianti (2016) claimed that by controlling the media the authorities can manipulate the information they want to communicate to the public. The findings showed that while the Internet provided an alternative way to voice their opinions, the effectiveness of the Internet actually depends on the way users use it. Results of the interviews with Malaysian opinion leaders on the current legal consequences of Malaysian laws (especially media-related laws) and on how the people are to voice their opinions online, revealed that citizens were not very brave to voice their opinions because of the restrictive laws. 
Congruent to the above study, the work of Junaidi Awang and Mohd Fuad's (2015) also revealed a similar trend, where the Internet and social media play an important role in influencing the political behavior of university students. Their findings also showed that unlike the students who were critical of current issues, the intellectuals supported the university administration and government of the day.

The above studies reviewed thus far have shown the increasing use of social media in politics. This is largely made possible by the democratisation of information in the advent of the Internet and its related applications. With this development, the present study positions itself to assess the political agenda via social media in the realm of political support among university students.

\section{THEORETICAL FRAMEWORK}

Today's social media has created a new wave of information spread and the Agenda Setting Theory plays an important role in this phenomenon. The original idea of the theory only demonstrates the power of the mass media as setting the agenda in the news and so forth. However, today, social media domination is demonstrated through various research conducted by experts and this study also aimed to determine the dominance of social media as a medium for political support among the youth. The theory used in this study is the Agenda Setting Theory proposed by McCombs and Shaw (1972). McCombs and Shaw (1972) believe the agenda-setting theory illustrates the ability of the media to influence the importance placed on a topic of public agenda. By setting the agenda, it also tries to make predictions. If a news item is often reported with clarity and emphasis, the audience will consider the issue to be more salient.

The Agenda Setting Theory is centered on how the media exploit or direct a news item or information directly to the public. Currently, social media platforms in Malaysia have a strong influence on the political structure and they are interconnected. Social media provide the platform for political candidates to present their agendas to generate political support. These social media platforms include Facebook, Twitter and WhatsApp.

The public agenda in the Agenda Setting Theory should be relooked, considering the nature of today's audience living in the digital environment of social media. Hence, the Agenda Setting Theory needs to be reviewed as the public agenda has taken a centre stage through social media (Ali et al., 2016). The public agenda refers to the public themselves giving feedback or comments to the agenda they think are of interest and benefit to their wellbeing, including political agenda. According to Simarmata (2014), social media have now created a new platform of new public space. This space has opened up a great opportunity for the public to politicise while pushing for political support. The public agenda can be divided into two major aspects of offline and online engagement.

Along with rapidly developing technology, people nowadays have various options in gaining information through various media environments, especially on social media. They do not only rely on mass media but are becoming increasingly dependent on social media to get current information. The social media culture that sparked this phenomenon did not only become the beginning of the existence of various news and information channels, but also an important factor that affects the lives of society, especially the youth. Social media are now the current tools that play an important role and have become platforms for disseminating the 
latest information. In the past, the human world had experienced or faced the era of print media explosion in the 17 th century.

Social media have indeed attracted the attention of many Malaysians. The netizens in Malaysia are more likely to use the Internet for leisure activities that combine with networking features of OTT (Over the Top) messages, such as Facebook, Whatsapp and participation in informal forums (Mohd Hamdan, 2017). Communities use social media with a variety of purposes such as communicating with family members, email, education, information, searching for news and so on.

However, there is a space of probability that the purpose of using social media gives an impact to politics. This is because a large number of societies today use social media as sources of political information due to their accessibility and ubiquitous nature. As such, society is likely to be affected by political-oriented news and visions that are being injected through social media, indirectly contributing to political support (Mohd Hamdan, 2017).

Hence, the Agenda Setting Theory is found suitable and applicable in this study to enable the researchers to determine and evaluate the use of social media that can influence political support among university students, which may translate into positive behaviors in accordance with the rules of socio-political norms.

\section{HYPOTHESES OF THE STUDY}

Deriving from the literature review and theoretical framework, the researchers have proposed and set to test the following hypotheses:

Hypothesis 1: There is a significant relationship between the purpose of using social media and political support.

Hypothesis 2: There is a significant relationship between the political agenda on social media and political support.

\section{Place of Study}

\section{METHODOLOGY}

In order to obtain relevant data in line with the study, selecting the appropriate place as per the purpose of the study is crucial. Thus, the study was conducted at two public universities in Malaysia, namely Universiti Kebangsaan Malaysia (UKM) and Universiti Putra Malaysia (UPM). UKM, the third oldest university in Malaysia, is located in Bangi and was established on May 18, 1970. There are three UKM campuses throughout Malaysia comprising 13 faculties, 14 institutes and 12 centres. UPM, the second oldest university in Malaysia, is located in Serdang and was officially launched in 1931 with 16 faculties, 9 institutions and 4 centres. Studies focusing on the political role of social media will certainly be appropriate if it is conducted at a university as it will reveal some interesting insights. This is because the university is home to many young people full of new ideas. 


\section{Research Design}

The study employed a quantitative method to obtain data from the sampled students. Leedy and Ormrod (2001) with Williams (2007) observe that quantitative methods are specific in measuring and testing, as they are built on existing theories. The quantitative method uses numerical data and involves statistical analysis of the data to understand and explain the phenomenon to be studied. The use of statistical tests is to clarify or find relationships between variables in a study (Mat Pauzi \& Shahizan Ali, 2016). The survey method is more appropriate to this study as it involves a representative sample and the data obtained from the questionnaire can be generalised to represent the phenomenon in the student population. In this study, the questionnaire was used to obtain data on demography, the independent variables (the purpose of internet usage, social media agenda, political agenda on social media, public agenda) and their relationship with political support among university students.

\section{Sampling, Data collection and Analysis}

To determine the selection of respondents to represent the population of the study, nonprobability sampling was used. Simple random sampling was not suitable as the target population in this study is not uniform. A total of 200 questionnaires consisting of five sections were administered among the respondents. The data was collected and analysed in early 2018 using the Statistical Package for Social Sciences (SPSS 22.0) software and the analysis was based on the objectives and hypotheses of the study. Pearson Correlation was used to examine whether there was a significant relationship between the independent and dependent variables. Hence, both descriptive and inferential analysis were carried out to analyse the data.

\section{Pilot Study}

Prior to conducting the actual study, a pilot study (Table 1) was conducted on a sample of 30 respondents. The results of the Cronbach's Alpha of the pilot and actual studies showing reliability of the variables are presented in Table 1. From the table, all the variables show a high score depicting a high reliability of the research instrument used in the study. A Cronbach Alpha value of 0.6 and above is said to be acceptable (Pallant 2001).

Table 1: Cronbach's Alpha of the Pilot and Actual Study

\begin{tabular}{lccc}
\hline \multicolumn{1}{c}{ Variables } & \multicolumn{2}{c}{ Cronbach's Alpha } & No. of Items \\
& Pilot Study & Actual Study & \\
\hline Purpose of using social media & 0.843 & 0.943 & 19 \\
Political Agenda on Social media & 0.953 & 0.954 & 8 \\
Political Support & 0.890 & 0.954 & 13 \\
\hline
\end{tabular}

\section{Respondent Demographic Profile}

\section{RESULTS}

In this study, 200 respondents were sampled to represent the entire student population of the two public universities namely Universiti Kebangsaan Malaysia (UKM), Bangi campus and Universiti Putra Malaysia (UPM), Serdang campus. The demographic profile is divided into four aspects: gender, age, academic qualifications and work. Respondents were selected based on stratified sample comprising 98 males and 102 females from UKM and UPM. Most of the 
respondents were pursuing bachelor degrees. All the respondents who were sampled for the study had experience using social media or online media.

Table 2: Respondents' Demographic Profile

\begin{tabular}{lcc}
\hline \multicolumn{1}{c}{ Demography } & Frequency & Percentage \% \\
\hline Gender & 98 & \\
Male & 102 & 49.0 \\
Female & & 51.0 \\
Age Group & 75 & \\
$19-21$ & 107 & 37.5 \\
$22-24$ & 27 & 53.5 \\
25 and above & & 9.0 \\
Level of Degree & 173 & \\
Bachelor Degree & 24 & 86.5 \\
Masters Degree & 3 & 12.0 \\
PhD & & 1.5 \\
Occupation & 14 & \\
Civil Servant & 2 & 7.0 \\
Private sector & 184 & 1.0 \\
Full time Student & & 92.0 \\
\hline $\mathrm{N}=200$ & &
\end{tabular}

Table 2 shows the demographic profile of respondents. The 200 respondents comprised of 49 percent male and 51 percent female. The breakdown for the age groups is 19-21 (37.5\%), $22-24(53.5 \%)$ and 25 and above (9\%). It is clear that the respondents aged 22-24 are the most sampled. The number of respondents studying Bachelor's degree was 86.5 percent, Master degree was 12 percent and Doctoral degree was only 1.5 percent or 3 respondents.

Furthermore, Table 2 shows the distribution of respondents according to occupation, where the percentage of civil servants is 7 , while those working in the private sector made up 1 percent. Meanwhile, the percentage of full time students is 92 . The 16 students who are working and studying are part-time students pursuing postgraduate programmes.

\begin{tabular}{|c|c|c|}
\hline Types of Social media & Frequency & Percentage \% \\
\hline Facebook & 185 & 92.5 \\
\hline WhatsApp & 151 & 75.5 \\
\hline Instagram & 129 & 64.5 \\
\hline Twitter & 12 & 61.5 \\
\hline Blog & 49 & 24.5 \\
\hline Telegram & 46 & 23.0 \\
\hline Wechat & 38 & 19.0 \\
\hline Line & 15 & 7.5 \\
\hline
\end{tabular}


The type of social media most used by university students to get general information (Table 3) is Facebook (92.5\%). This is followed by WhatsApp (75.5\%). Meanwhile, Instagram (64.5\%) ranked third and 61.5 percent used Twitter for their general information needs. The least used social media app to source information is Line (7.5\%).

Table 4: Sources of Political Information

\begin{tabular}{lcc}
\hline \multicolumn{1}{c}{ Sources } & Frequency & Percentage \% \\
\hline Social media \& Communication App & 151 & 75.5 \\
Television & 144 & 72.0 \\
Newspaper & 141 & 70.5 \\
Online News Portal & 123 & 61.5 \\
Family & 113 & 56.5 \\
Friends & 101 & 50.5 \\
Radio & 95 & 47.5 \\
Magazine & 75 & 37.5 \\
Blog & 64 & 32.0 \\
Colleagues & 31 & 15.5 \\
Party Representative & 27 & 13.5 \\
Community/Vilage Head & 17 & 8.5 \\
\hline N=200 & &
\end{tabular}

An important aspect of interest for the researchers of this study is to uncover the main sources of political information for the students (Table 4). Among the channels most widely used as sources for political information by the respondents were social media and communication applications (75.5\%). Television is the second most widely used source for political information by the students (72\%). Some 70.5 percent of the respondents used newspapers as a source for political information, while online news portals recorded 61.5 percent. Less than half of the respondents $(47.5 \%)$ said radio was the source for their political information. Slightly more than half $(56.5 \%)$ of the respondents got their political information from their family members. On the other hand, 50.5 percent of the respondents said friends were their source for political information. The least-used source for political information among the respondents is community/village head (8.5\%).

Table 5: Daily Hours of Using Social media

\begin{tabular}{lcc}
\hline \multicolumn{1}{c}{ Daily Hours } & Frequency & Percentage \% \\
\hline 6 Hours or more & 73 & 36.5 \\
4-5 Hours & 83 & 41.5 \\
1-3 Hours & 43 & 21.5 \\
Less than 1 Hour & 1 & 0.5 \\
\hline $\mathrm{N}=200$ & &
\end{tabular}

Table 5 presents the number of hours the university students used social media in a day. Most repondents (41.5\%) spent four to five hours on social media, while 36.5 percent were on social media for six or more hours per day. Additionally, 21.5 percent of the respondents used social media for one to three hours in a day. Only 0.5 percent of the respondents used social media for less than one hour a day. It is evident that the majority of the university students 
spent four to five hours using social media in a day, indicating the prevalence of social media in their daily lives.

\section{Purpose of Using Social Media}

From the data shown in Table 6, the highest mean score for the purpose of using social media belongs to communication with colleagues and friends $(M=6.13, S D=1.15)$. This is followed by communication with family members $(M=6.11, S D=1.21)$. It is clear here that the majority of students in UKM and UPM tend to use social media to connect with their family members, colleagues and friends. Using social meda for social communication ( $M=5.97, S D=1.20)$ was also remarkable. Overall, the standard deviation is not greater than the mean score. Thus, there is no remarkable common deviation in the purpose of using social media by university students.

Table 6: Purpose of Using Social Media and Communication Apps

\begin{tabular}{lcc}
\hline \multicolumn{1}{c}{ Types of Social media } & Mean* & Standard Deviation \\
\hline Communication with colleagues/friends & 6.13 & 1.15 \\
Communication with family members & 6.11 & 1.21 \\
Social Communication & 5.97 & 1.20 \\
Searching for local current news/issues & 5.43 & 1.27 \\
Hobby/games/entertainment & 5.38 & 1.35 \\
Buying product online & 5.01 & 1.65 \\
Selling product online & 4.16 & 1.95 \\
\hline *Mean = 1 (Strongly disagree) - 7 (Strongly agree) & &
\end{tabular}

\section{Political Agenda on Social Media}

From the data shown in Table 7, majority of the respondents agree that social media provide information to understand the political issues in the country $(M=5.01, S D=1.36)$. They also agree that social media empowers the people to share information about political matters $(M=5.00, S D=1.33)$. Meanwhile, among the political agenda in social media, the least functional agenda, as agreed by the students, is that social media provide a promising space for people to create or produce political content $(M=4.62, m=1.51)$.

Table 7: Political Agenda on Social Media

\begin{tabular}{|c|c|c|}
\hline Types of Social media & Mean* & Standard Deviation \\
\hline Social media provides information for understanding political issues & 5.01 & 1.36 \\
\hline Social media empower the people to share information about politics. & 5.00 & 1.33 \\
\hline Social media help the people to get interested in political issues. & 4.85 & 1.45 \\
\hline $\begin{array}{l}\text { I am more optimistic in using social media for political affairs as compared } \\
\text { with conventional media. }\end{array}$ & 4.84 & 1.55 \\
\hline $\begin{array}{l}\text { Social media have the advantage in chanelling political information as } \\
\text { compared with conventional. }\end{array}$ & 4.82 & 1.48 \\
\hline The people are happy to get political information through social media. & 4.79 & 1.45 \\
\hline $\begin{array}{l}\text { Social media provide equal opportunity and power in sharing political } \\
\text { information to the people. }\end{array}$ & 4.75 & 1.49 \\
\hline $\begin{array}{l}\text { Social media guarantee a space for the people to create / produce political } \\
\text { content. }\end{array}$ & 4.62 & 1.51 \\
\hline
\end{tabular}




\section{Political Support}

The extent to which social media have impacted on respondent political support is worth examining. Over the years, social media have had an impressive impact on university students in terms of political support. From the data shown in Table 8, the item with the highest mean score $(M=4.61, S D=1.74)$ reflects that social media strengthens the democratic system in Malaysia. The students agree that social media enhance the image of political candidates and their parties ( $M=4.50, S D=1.61)$. However, the students were not that happy $(M=3.74, S D=1.92)$ as getting feedback on their personal issues from political parties was a bit slow. Overall, the standard deviation is not greater than the mean score, hence, there is no remarkable common deviation in political support.

Table 8: Political Support

\begin{tabular}{|c|c|c|}
\hline Types of Social Media & Mean* & Standard Deviation \\
\hline Social media influence me in supporting a political candidate & 4.23 & 1.57 \\
\hline Social media help me in a political party & 4.13 & 1.57 \\
\hline Social media improves the image of of candidate and political party. & 4.50 & 1.61 \\
\hline Social media improves my relationship with political candidate. & 3.82 & 1.58 \\
\hline $\begin{array}{l}\text { I see social media showcasing the activities of candidates in providing } \\
\text { service to the people }\end{array}$ & 4.32 & 1.63 \\
\hline Information provided by social media about political party can be trusted & 4.16 & 1.64 \\
\hline I always get information about party activities through social media. & 4.37 & 1.55 \\
\hline $\begin{array}{l}\text { It is easy for me to get political information } \\
\text { through Social media. }\end{array}$ & 4.40 & 1.60 \\
\hline $\begin{array}{l}\text { I am given the opportunity to provide feedback on politics through social } \\
\text { media. }\end{array}$ & 4.15 & 1.72 \\
\hline $\begin{array}{l}\text { I always get quick feedback about my personal issues from political party } \\
\text { through social media }\end{array}$ & 3.74 & 1.92 \\
\hline $\begin{array}{l}\text { Social media have attracted my interest to } \\
\text { involve in politics. }\end{array}$ & 3.92 & 1.84 \\
\hline $\begin{array}{l}\text { In general, I feel social media have strengthened the democratic system } \\
\text { in Malaysia. }\end{array}$ & 4.61 & 1.74 \\
\hline
\end{tabular}

Correlation Analysis of the Independent Variables and Political Support

Table 9 shows the correlation analysis of the independent variables and political support. Pearson correlation was used to test the hypothesis and based on the Guildford's Rule of Thumb the strength of the $r$ value is determined.

Table 9: Correlation Analysis of the Independent Variables and Political Support

\begin{tabular}{lcc}
\hline \multicolumn{1}{c}{ Independent Variables (IVs) } & $\boldsymbol{r}$ & Political Support \\
& $\boldsymbol{p}$ & .000 \\
\hline Political Agenda on Social Media & $0.647^{* *}$ & .000 \\
Purpose of using Social Media & $0.358^{* *}$ & \\
\hline
\end{tabular}

$\mathrm{N}=200$

** Correlation is significant at the 0.01 level (2-tailed) 
Hypothesis Testing

The following are the hypothesis tested in this study:

Hypothesis 1: There is a significant relationship between the purpose of using social media and political support.

The Pearson correlation shows the value of $r$ as 0.358 and based on Guildford's Rule of Thumb the $r$ value depicts a weak correlation. The result of the test shows that the significant value $(p)$ is 0.000 which is smaller than the value of alpha $0.01(p<0.01)$. This shows that there is a significant, but weak positive relationship between the purpose of social media usage and political support, hence, hypothesis 1 is accepted $[r(200)=0.358, p<0.01]$.

Hypothesis 2: There is a significant relationship between the political agenda in social media and political support.

Hypothesis 2 tests the relationship between political agenda in social media and political support. The Pearson correlation result shows a value of $r=0.647$ indicating a moderate positive correlation. The result of the test shows that the significant value (p) is 0.000 which is smaller than the value of alpha $0.01(p<0.01)$. This suggests a significant relationship between political agenda in social media and political support, hence, hypothesis 2 is accepted $[r(200)=$ $0.647, p<0.01]$.

\section{DISCUSSION}

With the advent of social media, political information is now at the fingertips of every Malaysian, especially those living in urban areas and having ubiquitous access to the Internet. Youth, especially university students, need not have conventional media such as radio, television or newspapers to understand what is going on in the political arena. Social media, especially Facebook, Twitter and WhatsApp have made access to information so easy for larger populations. Diverse news sources, including social media platforms, are vital to fulfilling the aspirations of civil society in terms of news consumption (Sharafa \& Nik Norma, 2018).

Today's social media function has opened up a huge space for political power to be influenced by youth through this medium. Based on the findings from the survey conducted on 200 sampled respondents, it has been shown that social media play a big role in political support among university students. The findings of this study is congruent to Junaidi Awang et al. (2013) that social media have attracted the attention of all groups and even the youths, especially university students who make social media a means for obtaining information, including political information. This could be due to the nature of information on online media, which is free of control as evident in the way news is framed as compared to conventional media (Tung \& Murudi, 2019).

There are several important findings that have been obtained and the focus of the discussion is on the main findings of the study. The findings show that university students often use social media applications as sources of information to guide them in their daily activities. The study by Ali, Iqbal and lqbal (2016) echoed similar findings, that social technologies such as 
social media have affected most of the youth's life. Siti Ezaleila (2016) also concurred that social media is an extension of offline interaction and that social media will replace other information and communication media in the near future. Congruent to the studies cited, the present study finds that, indeed, university students are now more likely to use social media applications as sources of information than other sources such as newspapers, television, magazines and so on. This is a developing trend of the influence of the Internet and social media in the delivery of information, politics included.

The study also finds that the main purpose of using social media by university students is to communicate with friends, to contact family members and to obtain educational information. The findings concur with the previous study carried out by Siti Ezaleila (2016) which finds that most students use social networking sites for social purposes and frequently receive information. Social media is indeed a great platform for communication and for the public to voice their agenda. In the correlation analysis, it was evident that the relationship between public agenda in social media and political support was the strongest.

In contrast to Junaidi Awang and Mohd Fuad (2015), who examined the use of Internet and political perceptions of students, examining the influence of social media on student political behaviour, this study focuses on political agenda in social media towards political support. This study found that political agenda in social media plays a role in political support. Social media provide the latest political information and space to ensure the participation of youth. The findings of Junaidi Awang and Mohd Fuad (2015) point out that the current source of information from social media has transformed the country's political landscape and sparked democratisation of information at a broader and faster rate compared to mainstream media. The researcher attributes social media as an important source of information in delivering political agendas to the public. The same study by Junaidi Awang Besar also noted that respondents who access print and electronic media are more likely to support Barisan Nasional while respondents who access alternative sources such as blogs and social media are more likely to support parties in the Opposition Pact. This was evident in the recent $14^{\text {th }}$ General Elections where the opposition pact, Pakatan Harapan used social media, especially Facebook to air their campaigns.

The public agenda which is translated into political agenda is a concept where public opinion is at the centre of discussion, especially political discussion, which centres on the public's opinions through social media (Ali et al., 2016). Public political agenda on social media in this study has shown that university students are more active in online politics than offline and indirectly voice their opinions on political issues through social media as a form of political support. The study by Ali et al. (2016) discovered that social media, especially Facebook and Twitter, played an important role in forming public opinion on political matters. Similarly, this study found that the public agenda in social media had a direct and significant relationship with political support where university students agreed that today's social media provide a great space for them to get involved in politics and this was evident by the Pearson correlation analysis carried out showing a strong relationship between public agenda on social media and political support.

Furthermore, the results of this study can be compared with the study conducted by Budiyono (2016). His research has shown that Facebook is used by Indonesian political party candidates to deliver their political agenda and the audience are free to give negative or 
positive comments on the agenda. This further strengthens the notion of a relationship between the public's political views on candidates and political support through online media.

\section{CONCLUSION}

Overall, it can be concluded that the objectives of this study have been met. The study has shown that there is a relationship between the purpose of using social media, political agenda in social media and political support among university students. This is an important finding as it illustrates the shift where the influence of social media on political support, which was once dominated by conventional media, is eminent.

The findings also highlight that, today's university students prefer to use online and social media rather than conventional media, to obtain news. This technology transfer should be studied further as there are also the advantages and disadvantages of social media that should be highlighted. Furthermore, the findings show that university students express their political opinions through social media, and they are also more oriented discussing politics online than offline. The paper has also successfully exposed the social media agenda which is more geared towards a positive direction where the university students understand that social media agenda is to convey government information and policies to them.

Thus, this paper has contributed to the phenomenon of social media influence on politics, especially among university students. The most recent Malaysia 14th General Election was a testimony to the power of social media, where a large number of younger voters who sourced political information through social media voted for Pakatan Harapan. Overall, this paper has provided useful social media insights for politicians, governments, organisations, academia and the community as a whole, especially in politics among university students and its capability in paving the way for improvements in national media policy.

\section{ACKNOWLEDGEMENT}

This study was funded by DPP-2015-109: Media and Democracy Research Grant from Universiti Kebangsaan Malaysia.

\section{BIODATA}

Ali Salman (PhD) is an Associate Professor at the Centre for Language Studies and generic Development, Universiti Malaysia Kelantan. His research interests include new media, digital inclusion and audience study. Email: asalmanphd@gmail.com or ali.salman@umk.edu.my

Mohd Azul Mohamad Salleh (PhD) is a Senior Lecturer at the Centre for Research in Media and Communication, Faculty of Social Sciences and Humanities, Universiti Kebangsaan Malaysia. His research interests include communication technology, new media and online satisfaction. Email: azul@ukm.edu.my 


\section{REFERENCES}

Ahmad Nidzamuddin Sulaiman. (2002). Ahmad Nidzamuddin. In Abdul Monir Yaacob \& Suzalie Mohamad (Eds.), Etika dan budaya berpolitik dari perspektif Islam. Kuala Lumpur: IKIM.

Ali, A., Iqbal, A., \& Iqbal, K. (2016). Effects of social media on youth: A case study in University of Sargodha. International Journal of Advanced Research, 4(11), 369-372.

Ali Salman, Normah Mustaffa, Mohd Azul Mohd Salleh, \& Mohd Nor Shahizan Ali. (2016). Social media and agenda setting: Implications on political agenda. Jurnal Komunikasi: Malaysian Journal of Communication, 32(1), 607-623.

Ali Salman, \& Samsudin A. Rahim. (2012). From access to gratification: Towards an inclusive digital society. Asian Social Science, 8(5), 5-15.

Budiyono. (2016). Media sosial dan komunikasi politik: Media sosial sebagai komunikasi politik menjelang Pilkada DKI Jakarta 2017. Jurnal Komunikasi, 11(1), 47-62.

Uzuegbunam, C. E. (2015, September). Young people's engagement of social media for social transformation: Study of Nigerian university students. Online Journal of Communication and Media Technologies, Special Issue, 171-194.

Fatimah Akmal, \& Ali Salman. (2015). Partisipasi politik belia secara 'online' melalui ruang demokrasi maklumat media baru. Jurnal Komunikasi: Malaysian Journal of Communication, 31(1), 81-100.

Junaidi Awang Besar, \& Mohd Fuad Mat Jali (2015). Pengaruh media terhadap pilihan parti politik dalam kalangan mahasiswa universiti awam di Lembah Klang. Jurnal Personalia Pelajar, 18, 11-22.

Junaidi Awang Besar, Mohd Fuad Mat Jali, Novel Lyndon, \& Mazlan Ali. (2013). Penggunaan internet dan persepsi politik mahasiswa Universiti Kebangsaan Malaysia (Internet use and political perceptions of Universiti Kebangsaan Malaysia Students). Jurnal Personalia Pelajar, 16, 1-13.

Kahne, J., \& Bowyer, B. (2018). The political significance of social media activity and social networks. Political Communication, 35(3), 470-493.

Lim, Y. (2013, February 27). PM: GE13 will be Malaysia's 1st 'social media election'. The Star Online. Retrieved from http://thestar.com.my/news/story.asp?file=/2013/2/27/nation/20130227190736\&sec= nation

McCombs, M. E., \& Shaw, D. L. (1972). The agenda-setting function of the mass media. Public Opinion Quarterly, 36, 176-85.

Mohd Hamdan Adnan. (2017). Internet usage among Sabah civil servants and it's impact on their consumers behavior. Journal of Borneo Kalimantan, 3(1), 33-43.

Milbrath, L. W. (1965). Political participation. Chicago: Rand McNally College Publishing Company.

Nuurrianti Jalli. (2016). The effectiveness of social media in assisting opinion leaders to disseminate political ideologies in developing countries: The case of Malaysia. Jurnal Komunikasi: Malaysian Journal of Communication, 32(1), 551-579.

Pallant, J. (2001), SPSS survival manual - A step by step guide to data analysis using SPSS for windows (version 10). Buckingham, UK: Open University Press. 
Sharafa Dauda, \& Nik Norma Nik Hasan. (2018). Framing the sustainable development goals in Malaysian online news. SEARCH Journal of Media and Communication Research, 10(1), $1-24$.

Simarmata, S. (2014). Media baru, ruang publik baru, dan transformasi komunikasi politik di Indonesia. Prodi IImu Komunikasi. Retrieved on 4 December 2017.

Siti Ezaleila Mustafa. (2016). Penggunaan laman sosial dan impaknya terhadap hubungan persahabatan dalam talian. Jurnal Komunikasi: Malaysian Journal of Communication, 32(2), 65-81.

Ting, S. H., \& Murudi, T. (2019) Framing of the 1MDB financial scandal: A comparative study of the coverage by The Star and Malaysiakini. SEARCH Journal of Media and Communication Research, 11(2), 113-126.

Utusan Online. (2015). Senjata paling berkuasa media sosial. Retrieved on 5 December 2017. 